\title{
LO'HAIRE BALL
}

\section{SteFAN DOWNEY NAJDECKI}

For twenty days and twenty nights, the fiddles screeched in a Fairy Hall, as the Prince learnt to dance a lo'haire ball. his feet did twirl 'long the hall his hands did fly with grace as he learnt to dance a lo'haire ball.

For twenty days and twenty nights, the pipes did roar in a Fairy Hall as the Princess learnt a lo'haire ball her dress did soar 'long the hall her hair did twirl with flair As the Princess danced a lo'haire ball.

For twenty days and twenty nights, the drums did thunder in a Fairy Hall as the Priest learnt to dance a lo'haire ball For one long day and one drunken night, the chorus cheered in a Pixie Hall as the Pixie Clan danced a lo'haire ball their bodies did jive 'long the hall their tankards dry with spirits high as the Pixie Clan danced a lo'haire ball.

For one tired morning and one hungover day, the servants bemoaned the Fairies, all. The Pixie Clan swept the wedding hall their brooms did swish along the wall their spirits sunk as sunlight did wane As the Pixie Clan wished the noble's house to shame. his bones did creak 'long the hall his body did fall with ache as the Priest stumbled a lo'haire ball. 